\title{
Serum Cholesterol and Cancer Mortality in Japanese Civil Service Workers : Findings from a Nested Case-control Study
}

\author{
Akiko Tamakoshi' ${ }^{1}$ Yoshiyuki Ohno', Takuji Yamada ${ }^{1}$, Kunio Aoki', \\ Takashi Kawamura ${ }^{1}$, Sadao Suzuki ${ }^{1}$, Kenji Wakai ${ }^{1}$, and Rie Nakamura ${ }^{1}$
}

\begin{abstract}
To examine an association between serum cholesterol level and cancer mortality, a nested case-control study was conducted among 5,796 civil service workers in Japan who underwent periodic health examination. One-hundred and thirty-one deaths (cases), including 73 cancer deaths, were identified in the study period from 1980/1981 to September 1, 1991. Two controls were randomly selected for each case, matched for age, sex, year of examination and job status.

As a major result, an increase in serum cholesterol of $10 \mathrm{mg} / \mathrm{dl}$ significantly reduced cancer risk by 0.91 times in men, but not in women. This reduction of cancer risk in men was found not to be confounded by body mass index (BMI), smoking habits, and drinking habits. No significant association could be found between serum cholesterol level and specific sites of cancer. Separate analysis by follow-up period significantly revealed an inverse association between serum cholesterol and cancer deaths in men in 6 years or later after serum measurement. This inverse association was believed not to be ascribable to an effect of a preclinical cancer. J Epidemiol, $1993 ; 3$ : 99-107.
\end{abstract}

serum cholesterol, nested case-control study, cancer, mortality

Many prospective epidemiological studies have examined the relationship between serum cholesterol level and ischemic heart disease, and indicated that its high mortality rate was largely ascribable to high serum cholesterol level particularly in the developed countries. An association of total mortality with serum cholesterol is, however, unique. Higher mortality was apparent in lower serum cholesterol populations as well as in higher serum cholesterol populations ${ }^{1-9)}$. This relation essentially implies higher mortality from diseases other than ischemic heart disease in lower serum cholesterol populations. Therefore, many studies have also examined the relationship between low serum cholesterol and total mortality, non-cardiovascular mortality or cancer mortality. In these studies, an inverse association of serum cholesterol level with cancer was confirmed ${ }^{1-5,10-33)}$.

In 1974, Rose and his colleagues reported an association of low cholesterol level with colon cancer $^{34)}$. Since then, numerous prospective studies have been undertaken to examine this particular association. Some studies have found no association between cholesterol level and cancer ${ }^{6,35-44)}$. An inverse association has been demonstrated in many studies, in which the association was mainly observed in $\operatorname{men}_{17-19,21-25}^{1-5,10-14}$, smoking-related cancers ${ }^{6,18-20)}$, and patients diagnosed or dead within a few years after cholesterol measurement ${ }^{3,5,20-22,25-30)}$, though nowadays was reported that the association was found not only within a few years but also after many years of follow-up ${ }^{4,10-18)}$. In 1991, Law and Thompson ${ }^{45)}$ reviewed 33 published prospective studies, and reported a long-term inverse association of low serum cholesterol with cancer. Thus, low serum cholesterol is advancingly likely as a risk of cancer, but still remains controversial in several respects.

To our knowledge, in Japan where mean serum cholesterol is rather low, there were few published reports ${ }^{46)}$ which examined an association between cancers and serum cholesterol level, when excluded some

\footnotetext{
Received May 10,1993; accepted July 13, 1993

'Department of Preventive Medicine, Nagoya University, School of Medicine, Nagoya, Japan. ${ }^{2}$ Aichi Cancer Center, Nagoya, Japan.

Address for correspondence: Akiko Tamakoshi, Department of Preventive Medicine, Nagoya University, School of Medicine, 65 Tsurumai-cho Showa-ku Nagoya 466, Japan
} 
studies done in collaboration with other countries $^{25,27,47)}$. In the present study, therefore, we attempted to clarify an association between serum cholesterol level and cancer mortality among civil service workers in Japan, and to add a further evidence of a long-term inverse association between them.

\section{MATERIALS AND METHODS}

We conducted a nested case-control study among civil service workers who underwent periodic health examination in 1980 and 1981. Study population, identification of cases and control selection are as follows.

\section{Study population}

In 1980 and 1981, baseline and periodic health examinations were carried on a total of $5,796(4,153$ men and 1,643 women) civil service workers aged 25 , $30,35,40,45,50$, and 55 years old each year (response rate: 92\%). The examination included self-administered questionnaire, anthropometric measurement and physical examination, electrocardiogram (ECG), urinalysis, and biochemical blood test. Blood specimens were drawn under fasting condition. Information collected by self-administered questionnaire included past history of major diseases, current health status, family history, smoking and drinking habits, and preference for foodstuffs and taste. Smoking (drinking) habits were inquired to classify daily- smoker (drinker), occasional smoker (drinker), and exor non-smoker (drinker). For daily drinkers, alcohol consumption per day was estimated by assuming alcoholic volume of $27 \mathrm{~g}$ in $180 \mathrm{ml}$ of "sake", $633 \mathrm{ml}$ of beer, or 1 double glass of whisky. Serum cholesterol was measured enzymatically ${ }^{48}$.

\section{Identification of cases}

Study population was followed up to September 1, 1991 after examination. All dead subjects were identified among those who are continuously on active service and also among those retired, but subsequently supported by retirement pension. Causes of death, classified according to International Classification of Diseases (ICD-9), were routinely checked by reviewing documents sent to the pension office to notify the death of pensioners. Those who retired before September 1, 1991 and were not subsequently supported by pension, accounting for $11.8 \%$ ( 683 in number) of a total study population, were excluded from the present analysis, since their vital status could not be traced.

One-hundred and thirty-one deaths (94 deaths during active service and 37 deaths after retirement) were identified between the examination and September 1, 1991. Table 1 summarizes causes of death by sex and subsequent follow-up year. Seventy three deaths were due to cancers ( 60 men and 13 women), being accounted for $55.7 \%$ of 131 total deaths.

Table 1. Numbers of death by cause and follow-up year.

\begin{tabular}{|c|c|c|c|c|c|c|c|c|c|c|}
\hline \multirow{2}{*}{\multicolumn{2}{|c|}{ Follow-up year }} & \multicolumn{8}{|c|}{ Cause of death } & \multirow{2}{*}{ Total } \\
\hline & & Cancer ${ }^{11}$ & $\mathrm{CHD}^{2)}$ & $\mathrm{CVD}^{3)}$ & Liver $^{4}$ & Suicide $^{5)}$ & Accident $^{6\}}$ & Others & Unknown & \\
\hline \multirow[t]{5}{*}{ Men } & $0 \sim 1$ & 6 & 0 & 1 & 0 & 0 & 0 & 1 & 1 & 9 \\
\hline & $2 \sim 5$ & 17 & 2 & 1 & 4 & 2 & 1 & 6. & 1 & 34 \\
\hline & $6 \sim 8$ & 15 & 3 & 2 & 2 & 3 & 1 & 4 & 0 & 30 \\
\hline & $9 \sim 11$ & 22 & 1 & 2 & 3 & 0 & 0 & 4 & 2 & 34 \\
\hline & total & 60 & 6 & 6 & 9 & 5 & 2 & 15 & 4 & 107 \\
\hline \multirow[t]{5}{*}{ Women } & $0 \sim 1$ & 1 & 0 & 1 & 0 & 0 & 0 & 0 & 0 & 2 \\
\hline & $2 \sim 5$ & 7 & 0 & 1 & 0 & 0 & 0 & 3 & 0 & 11 \\
\hline & $6 \sim 8$ & 5 & 1 & 0 & 0 & 0 & 0 & 1 & 0 & 7 \\
\hline & $9 \sim 11$ & 0 & 0 & 0 & 1 & 0 & 2 & 1 & 0 & 4 \\
\hline & total & 13 & 1 & 2 & 1 & 0 & 2 & 5 & 0 & 24 \\
\hline Total & & 73 & 7 & 8 & 10 & 5 & 4 & 20 & 4 & 131 \\
\hline $\begin{array}{l}\text { 1) } \mathrm{C} \\
\text { 2) } \mathrm{Cl} \\
\text { 3) } \mathrm{C} \\
\text { 4) } \mathrm{Li} \\
\text { 5) } \mathrm{Su} \\
\text { 6) } \mathrm{Ac}\end{array}$ & $\begin{array}{l}\text { ncer; IC } \\
\text { HD; Cor } \\
\text { VD; Cere } \\
\text { ver; not } \\
\text { icide; IC } \\
\text { cident; I }\end{array}$ & $\begin{array}{l}-9 \text { codes in } \\
\text { nary Heart } \\
\text { rovascular } \\
\text { cluding liv } \\
-9 \text { codes in } \\
\text { D-9 codes }\end{array}$ & $\begin{array}{l}\text { uded } 140 \\
\text { isease, IC } \\
\text { isease, IC } \\
\text { cancer, I } \\
\text { uded E9 } \\
\text { cluded E }\end{array}$ & $\begin{array}{l}98 \\
-9 \text { codes } \\
-9 \text { codes } \\
\text { D-9 code } \\
959 \\
0-949 \text { an }\end{array}$ & $\begin{array}{l}\text { luded } 41 \\
\text { luded } 43 \\
\text { ncluded }\end{array}$ & $\begin{array}{l}414 \\
438 \\
-573\end{array}$ & & & & \\
\hline
\end{tabular}




\section{Control selection}

Controls were selected from the same population matching to cases for age (within 1 year), sex, year of examination, and job status (blue or white color worker). First, we constructed potential sources of controls for each case, and then two controls were randomly selected from each source by identifying those whose year of employment was the nearest and who are confirmed as alive on September 1, 1991. There was one case who succumbed to liver cancer, and for whom we could not set up two eligible controls. This pair was also included in the present analysis.

\section{Statistical methods}

Analyses were performed separately by sex to explore the relationship between serum cholesterol level and total mortality, cancer mortality from all sites, and mortality from major primary sites of cancer (stomach, lung, digestive organ cancers, smokingrelated cancers), when death occurred in 2 years or later after examination, i.e. excluding those who died in less than 2 years after examination, probably due to diseases already suffered. We included cancers of the esophagus, stomach, colon and rectum in cancer of the digestive organ. For men, smoking-related cancer was defined as cancers of the lung, mouth, larynx, esophagus, pancreas, bladder, and leukemia. For women, cancer of the cervix was also included ${ }^{19)}$ in smokingrelated cancer. The entire follow-up period was divided into three periods: (1) 2 to 5 years, (2) 6 to 8 years, and (3) 9 to 11 years. All statistical analyses were conducted using the SAS programs at Nagoya University Computation Center. For multivariate analysis, we used a conditional logistic regression model for matched data ${ }^{49}$. In multivariate analyses, body mass index (BMI : weight $(\mathrm{kg}) /$ height $(\mathrm{m})^{2}$ ), smoking habits, and drinking habits at baseline (1980 or 1981) were used as covariates.

\section{RESULTS}

Some selected characteristics of the study subjects are shown in Table 2. The cases were more likely to be non-drinkers and current smokers, but heavy drinkers defined as consumers of $81 \mathrm{~g}$ or more alcohol per day, appeared to be more prevalent among the cases. They also more frequently suffered from hypertension or hepatitis ; more often complaining of dizziness, weight loss or thirst at entry.

As shown in Table 3, there was no significant difference in mean serum cholesterol for "all causes" and "all causes except accident and suicide", though the mean values were consistently lower in the cases. For
Table 2. Characteristics of study subjects at entry.

\begin{tabular}{|c|c|c|}
\hline & $\begin{array}{c}\text { Case } \\
(\mathrm{n}=120)\end{array}$ & $\begin{array}{c}\text { Control } \\
(n=239)\end{array}$ \\
\hline \multicolumn{3}{|l|}{ Alcohol drinking } \\
\hline Non- drinker & $35.9 \%$ & $30.9 \%$ \\
\hline Heavy drinker ${ }^{1)}$ & $9.4 \% \#$ & $4.3 \%$ \\
\hline \multicolumn{3}{|l|}{ Smoking habits } \\
\hline Smoker (daily) & $66.1 \%$ & $57.7 \%$ \\
\hline \multicolumn{3}{|l|}{ Salty foods } \\
\hline Preferred & $21.2 \%$ & $22.8 \%$ \\
\hline \multicolumn{3}{|l|}{ Sweet foods } \\
\hline Preferred & $21.0 \%$ & $19.7 \%$ \\
\hline \multicolumn{3}{|l|}{ Oily foods } \\
\hline Preferred & $21.0 \%$ & $15.0 \%$ \\
\hline \multicolumn{3}{|l|}{ Amount of meal } \\
\hline Large & $8.3 \%$ & $6.8 \%$ \\
\hline \multicolumn{3}{|l|}{ Past history } \\
\hline Hypertension & $14.2 \% \#$ & $7.9 \%$ \\
\hline Hepatitis & $10.8 \% \#$ & $5.4 \%$ \\
\hline \multicolumn{3}{|c|}{ Subjective complaints } \\
\hline Dizziniss & $10.0 \% \#$ & $5.0 \%$ \\
\hline Weight loss & $8.3 \% *$ & $3.3 \%$ \\
\hline Thirst & $17.5 \% * *$ & $6.7 \%$ \\
\hline $\begin{array}{l}\#: p<0.1 \\
*: p<0.05 \\
*^{* *}: p<0.01: \text { test } \\
\text { " Heavy drinker }\end{array}$ & $\mathrm{ol} \geq$ & \\
\hline
\end{tabular}

"male cancer death", mean serum level was $177.3 \mathrm{mg} /$ $\mathrm{dl}$ in the cases and $190.5 \mathrm{mg} / \mathrm{dl}$ in the controls; being significantly lower in the cases. In women, however, mean serum cholesterol was not significantly different. Crude and two kinds of adjusted relative risks were also summarized in Table 3 . An increase in serum cholesterol of $10 \mathrm{mg} / \mathrm{dl}$ significantly reduced cancer risk by 0.91 times in men, but no reduction was noted in women. This reduction of cancer risk in men was found not to be confounded by BMI, smoking habits and drinking habits, since two adjusted relative risks were 0.89 (95\% confidence interval $0.81-0.98)$ and 0.87 (0.78-0.97).

Table 4 gives the relative risks of death from some sites of cancer in men. In women, numbers of death from specific sites of cancer are too small to calculate the relative risks. Lung cancer death tended to show a positive, and stomach cancer death a negative association with serum cholesterol. Risk of dying from cancers of the digestive organ and from smokingrelated cancers appeared to be lower, when serum cholesterol is higher. 


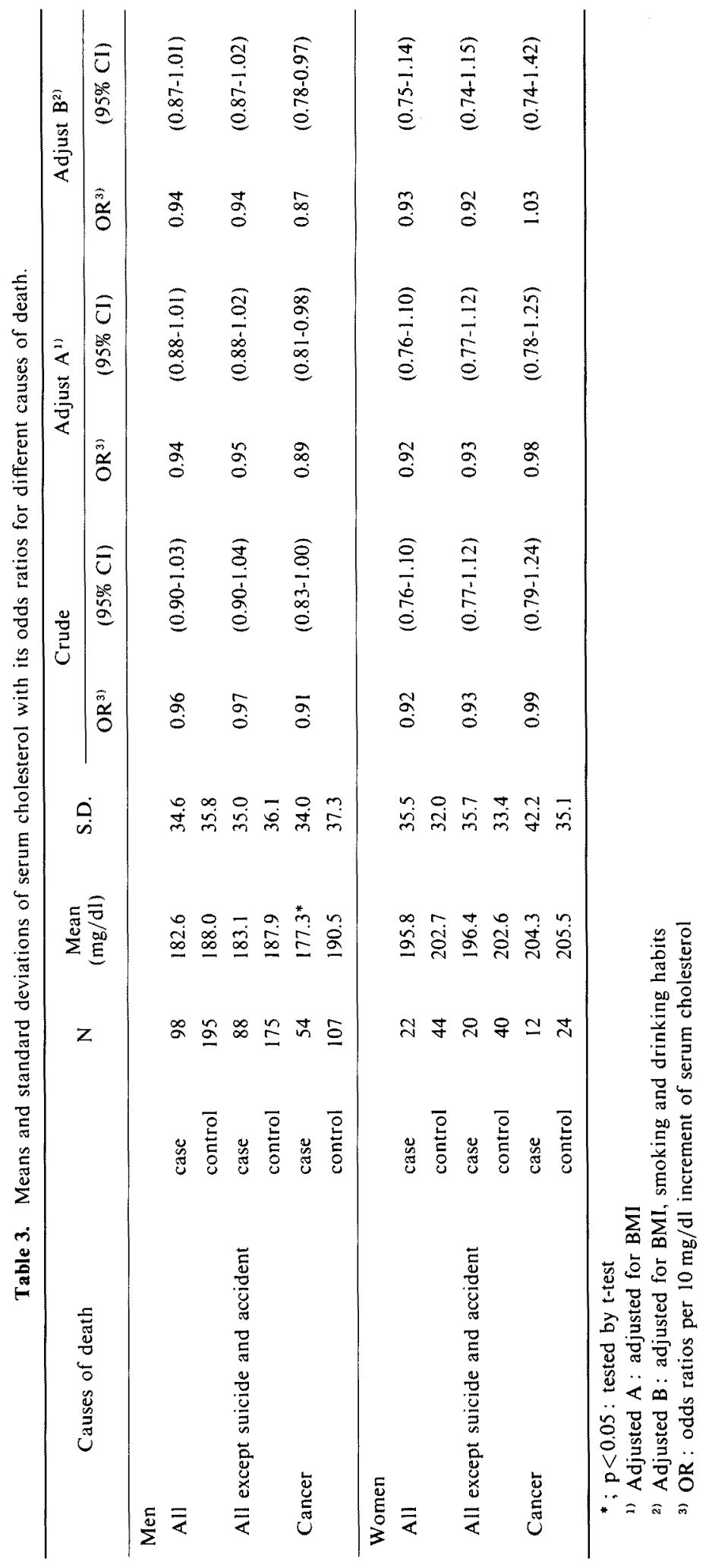


Table 4. Means and standard deviations of serum cholesterol with its odds ratios for deaths from specific sites of cancer (in men).

\begin{tabular}{|c|c|c|c|c|c|c|c|c|c|c|}
\hline \multirow{2}{*}{ Site of cancer } & & \multirow{2}{*}{$\mathrm{N}$} & \multirow{2}{*}{$\begin{array}{c}\text { Mean } \\
(\mathrm{mg} / \mathrm{dl})\end{array}$} & \multirow{2}{*}{ S.D. } & \multicolumn{2}{|c|}{ Crude } & \multicolumn{2}{|c|}{ Adjust $A^{11}$} & \multicolumn{2}{|c|}{ Adjust $\mathrm{B}^{2)}$} \\
\hline & & & & & $\mathrm{OR}^{33}$ & $(95 \% \mathrm{CI})$ & $\mathrm{OR}^{3)}$ & $(95 \% \mathrm{CI})$ & $\mathrm{OR}^{3)}$ & $(95 \% \mathrm{CI})$ \\
\hline \multirow[t]{2}{*}{ Lung cancer } & case & 11 & 196.8 & 35.4 & 1.06 & $(0.87-1.28)$ & 1.07 & $(0.87-1.31)$ & 1.04 & $(0.83-1.30)$ \\
\hline & control & 22 & 188.6 & 40.0 & & & & & & \\
\hline \multirow[t]{2}{*}{ Stomach cancer } & case & 12 & 185.1 & 36.2 & 0.94 & $(0.78-1.14)$ & 0.94 & $(0.78-1.14)$ & 0.89 & $(0.69-1.14)$ \\
\hline & control & 24 & 193.5 & 37.7 & & & & & & \\
\hline \multirow[t]{2}{*}{ Digestive organ cancers ${ }^{4}$} & case & 23 & 183.1 & 31.6 & 0.92 & $(0.81-1.05)$ & 0.90 & $(0.77-1.04)$ & 0.86 & $(0.73-1.02)$ \\
\hline & control & 46 & 196.9 & 40.9 & & & & & & \\
\hline \multirow[t]{2}{*}{ Smoking related cancers ${ }^{5}$} & case & 19 & 182.2 & 34.0 & 0.92 & $(0.79-1.06)$ & 0.95 & $(0.81-1.11)$ & 0.94 & $(0.79-1.11)$ \\
\hline & control & 38 & 194.4 & 34.9 & & & & & & \\
\hline
\end{tabular}

1) Adjusted $\mathrm{A}$ : adjusted for BMI

2) Adjusted B : adjusted for BMI, smoking and drinking habits

3) OR : odds ratios per $10 \mathrm{mg} / \mathrm{dl}$ increment of serum cholesterol

4) Digestive organ cancers; esophagus, stomach, colon and rectum

5) Smoking related cancers : lung, mouth, larynx, esophagus, pancreas, bladder, and leukemia

Table 5. Means and standard deviations of serum cholesterol with its odds ratios for total cancer mortality by follow-up period (in men).

\begin{tabular}{lllllllllll}
\hline \multirow{2}{*}{ Follow-up year } & $\mathrm{N}$ & $\begin{array}{c}\text { Mean } \\
(\mathrm{mg} / \mathrm{dl})\end{array}$ & S.D. & & \multicolumn{2}{c}{ Crude } & \multicolumn{2}{c}{ Adjust $\mathrm{A}^{1)}$} & \multicolumn{2}{c}{ Adjust B } \\
\cline { 6 - 11 } & & & & $\mathrm{OR}^{3)}$ & $(95 \% \mathrm{CI})$ & $\mathrm{OR}^{3)}$ & $(95 \% \mathrm{CI})$ & $\mathrm{OR}^{3)}$ & $(95 \% \mathrm{CI})$ \\
\hline $2 \sim 5$ & case & 17 & 187.0 & 35.6 & 1.06 & $(0.19-1.23)$ & 1.03 & $(0.87-1.21)$ & 1.09 & $(0.89-1.34)$ \\
& control & 34 & 178.4 & 38.3 & & & & & & \\
$6 \sim 8$ & case & 15 & $166.1^{*}$ & 29.5 & 0.86 & $(0.72-1.02)$ & 0.82 & $(0.67-1.00)$ & 0.77 & $(0.60-0.99)$ \\
& control & 29 & 188.6 & 36.3 & & & & & & \\
$9 \sim 11$ & case & 22 & $177.5^{*}$ & 34.7 & 0.84 & $(0.71-0.98)$ & 0.85 & $(0.72-1.00)$ & 0.83 & $(0.69-1.00)$ \\
& control & 44 & 201.1 & 34.9 & & & & & & \\
\hline
\end{tabular}

* ; $\mathrm{p}<0.05$ : tested by $\mathrm{t}$-test

1) Adjusted A : adjusted for BMI

2) Adjusted B : adjusted for BMI, smoking and drinking habits

3) $\mathrm{OR}$ : odds ratios per $10 \mathrm{mg} / \mathrm{dl}$ increment of serum cholesterol

Risk of cancer death with serum cholesterol was separately evaluated by follow-up period in men (Table 5). For the first period (follow-up 2-5 years), no association was obvious. For the second (followup 6-8 years) and the last period (follow-up 9-11 years), mean serum cholesterol were significantly lower in the cases, and an inverse association was statistically significant, when adjusted for BMI, and smoking and drinking habits. In women, however, no significant associations were noted in any follow-up periods between serum cholesterol level and cancer mortality (not shown in the text).

\section{DISCUSSION}

At first, we will discuss a few methodological shortcomings in our study and how we overcame them. First, the present study was based on relatively small numbers of cancer death. When case-control study is conducted based on small numbers of cases and controls, significant associations are not likely to be obtained. When a significant association is found, however, it may not be a distorted relationship between a given disease and a risk factor, unless cases and controls were selected with biases. Second, we could not trace all individuals in the study population up to September 1, 1991 to identify all dead subjects. 
The missed individuals were more likely to be women by sex, younger in men and older in women by age, compared to those who could be successfully traced. Thus, non-respondent bias could possibly exist in the present study, but we could not exclude this bias. Since some deaths were likely to be missed, we adopted the study design of a nested case-control study, in which cases were limitedly identified, and controls were definitely confirmed as survivors. This means, accordingly, that missclassification of cases and controls is not likely at all. Third, some studies have revealed an $U$-shape association of total mortality with serum cholesterol ${ }^{1-9)}$. According to our separate analysis by categorizing serum cholesterol into four levels, we found no U-shape association, but dose-response relationship with total mortality in men. We then handled serum cholesterol as a continuous variable, but not as a categorical variable, in our analysis.

As many other studies $2.10-13.17-20$ ), we found an inverse association between serum cholesterol and cancer mortality in men, but not in women. No apparent association in women might possibly be due to small numbers of cancer death in women, and partly to sex differentials in predominant sites of cancer ${ }^{18}$.

In several studies, low serum cholesterol was found to be inversely associated with colon cancer ${ }_{23,50-52,1,2,1,1,18}$, lung cancer $r_{23,25,32,33)}^{5,12,141,3}$ or smoking-related cancer $^{6,18-20}$. Our study, however, failed to demonstrate any significant associations between serum cholesterol level and specific sites of cancer, possibly because of small numbers of death from individual sites of cancer. A positive association with lung cancer deaths and negative association with deaths from smoking related cancers in our study, could not be readily explainable due to small number of deaths in these sites.

An association of low serum cholesterol level with cancer deaths was found in most reports $3,5,11,20-23,25-32$ ), when cancer deaths which occurred within a few years after cholesterol measurement were analyzed. This short-term association is believed to reflect an effect of preclinical cancer ${ }^{5\rangle}$ which lowered serum cholesterol. In our study all deaths which occurred in less than 2 years after examination were intentionally excluded. But in male patients who died in less than 2 years after cholesterol measurement, mean serum cholesterol was apparently lower by about $20 \mathrm{mg} / \mathrm{dl}$ when compared to their controls. This short-term effect was probably ascribable to increased catabolism resulting from enhanced low density lipoprotein (LDL)-receptor activity in malignant cells ${ }^{53}$. Henriksson and his colleagues ${ }^{54)}$, who compared prostatic cancer patients with and without metastasis and their controls, found that the patients with metastasis cleared LDL faster than those without metastasis and controls. According to this finding that indicates faster catabolism of LDL, a mechanism by which cancer reduces serum cholesterol is theoretically plausible.

In several studies ${ }^{4,10-18)}$, a long-term inverse association of serum cholesterol level with cancer was also obtained likewise our study. This long-term inverse association could not be explained by preclinical cancer, though implications of this association have not been fully understood. There are three possible explanations for the long-term inverse relationship between low serum cholesterol level and cancer. The first, it is just a chance observation; the second, a third factor will exist which lowers serum cholesterol and simultaneously increases the probability of cancer development ; and the third, low serum cholesterol itself actually causes cancer ${ }^{10,12,55-57)}$.

First, long-term association was found in $10^{4,10-18)}$ reports out of $29^{1-5,10-33)}$ cohort studies in which an inverse association of serum cholesterol level with cancer was reported. Law and Thompson ${ }^{45}$, who reviewed 33 published prospective studies by metaanalysis, confirmed a long-term association of low serum cholesterol with cancer. It may be, therefore, unlikely to be observed only by chance.

Second, a possible third factor may include smoking habits or beta-carotene. Since serum cholesterol is known to be pharmacologically lowered by smoking ${ }^{45)}$, serum cholesterol level could possibly be confounded by smoking habits. It is, however, found in most studies ${ }^{1,4,11-15,18,19,22-26,31,32)}$ including ours that an inverse association between serum cholesterol and cancer persisted even after statistical adjustment for smoking habits. Smoking is also known to lower high density lipoprotein (HDL) cholesterol ${ }^{58-61)}$. Most prospective studies have examined an association of cancers with total serum cholesterol except a few studies ${ }^{18,62,63)}$, in which an inverse association of serum HDL cholesterol with cancer was not consistently demonstrated. In our study, the relation with HDL cholesterol was examined as well, but no association with cancer mortality was found (unpublished data). Another possibility is that beta-carotene is a third factor to influence both cancer mortality and serum cholesterol level. Shekelle and his colleagues ${ }^{64)}$ reported that the association between low serum cholesterol level and increased risk of lung cancer did appear to be stronger in strata with low intake of beta-carotene than in the total cohort. And they hypothesized that betacarotene mediated the association between low serum cholesterol and increased risk of lung cancer. Though beta-carotene may possibly play an important role in a serum cholesterol-cancer relationship, there have been few prospective studies ${ }^{64)}$, which examined the interrelationship between serum cholesterol level and serum 
beta-carotene level or dietary intake of beta-carotene. There were also potential confounding factors which have been taken into account in previous studies; systolic blood pressure ${ }^{1,12-14,16,23)}$, relative weight ${ }_{25,32}^{14,152,24}$, educational level ${ }^{11,24,32)}$, alcohol consumption $n_{19,23,1,1,18,}^{4,1,}$ hematocrit ${ }^{24)}$, physical activity ${ }^{24)}$, or social class ${ }^{1.12 .15)}$. When adjusted for these variables, significant inverse associations between serum cholesterol and cancer were not altered ${ }^{65}$.

Third, if an association is real, a mechanism by which low serum cholesterol causes cancer should be rational. Isles and his colleagues ${ }^{12)}$ indicated the theoretical possibility that low cholesterol concentration predisposes directly to cancer, as cholesterol is an essential component of cell membranes. Kark and his colleagues $^{15)}$ also discussed that serum cholesterol levels may be associated predictively with a risk of developing certain cancers, possibly through an effect of serum cholesterol concentration on the characteristics of cell membranes, or by serum cholesterol levels reflecting membrane cholesterol levels. It is also possible that "malnutrition" expressed as "low serum cholesterol" may promote cancer development in some populations. According to Lowell and his colleagues ${ }^{66}$, laboratory studies have documented detrimental effects of malnutrition on host defenses and immune function by decreasing functions of lymphocytes, granulocytes, and macrophages. Since immune effector cells are known to mediate antitumor effects in vitro $^{67)}$, malnutrition may possibly be implicated in oncogenesis and/or the body's ability to control the development and spread of cancer by immune depression, though the overall mechanisms remain unknown.

Increasing dietary intake of saturated fat and cholesterol is known to increase serum cholesterol level ${ }^{68-71)}$, and international correlation was positive between per capita consumption of diets high in saturated fat and animal fat and cancer risk ${ }^{72,73)}$. This positive correlation is quite contradictory to low serum cholesterolcancer association. In 1992, Kritchevsky ${ }^{17}$, who examined the role of dietary fat and cholesterol, found that diet cannot explain the low serum cholesterolcancer association. Based on these discussions, it may probably be hypothesized that men with naturally occurring low levels of cholesterol are at an increased risk of cancer ${ }^{18,74)}$. To resolve this hypothesis, such researches as intervention trials of increasing serum cholesterol in low-serum-cholesterol populations may be needed.

In conclusion, we found a statistically significant inverse association between serum cholesterol level and cancer mortality in men. This inverse association was most apparent in 6 years or later after serum measurement. This finding was believed not to be ascribable to an effect of preclinical cancer.

\section{REFERENCES}

1. Kozarevic Dj, McGee D, Vojvodic N, et al. Serum cholesterol and mortality: the Yugoslavia Cardiovascular Disease Study. Am J Epidemiol, 1981; 114: 21-28.

2. Agner E, From Hansen P. Fasting serum cholesterol and triglycerides in a ten-year prospective study in old age. Acta Med Scand, 1983; 214:33-41.

3. Peterson B, Trell E, Sternby NH. Low cholesterol level as risk factor for noncoronary death in middle-aged men. JAMA, 1981; 245: 2056-2057.

4. Frank JW, Reed DM, Grove JS, Benfante R. Will lowering population levels of serum cholesterol affect total mortality? J Clin Epidemiol, 1992; 45: 333-346.

5. Rose G, Shipley MJ. Plasma lipids and mortality: A source of error. Lancet, 1980: i : 523-526.

6. Smith GD, Shipley MJ, Marmot MG, Rose G. Plasma cholesterol concentration and mortality. The Whitehall Study. JAMA, 1992; 267: 70-76.

7. Yaari S, Goldbourt U, Even-Zohar S, Neufeld HN. Associations of serum high density lipoprotein and total cholesterol with total, cardiovascular, and cancer mortality in a 7-year prospective study of $10,000 \mathrm{men}$. Lancet, 1981; i : 1011-1015.

8. Reed D, Yano K, Kagan A. Lipids and lipoproteins as predictors of coronary heart disease, stroke, and cancer in the Honolulu Heart Program. Am J Med, 1986; 80: 871.878 .

9. Martin MJ, Hulley SB, Browner WS, Kuller LH, Wentworth D. Serum cholesterol, blood pressure, and mortality: Implications from a cohort of 361,662 men. Lancet, 1986 ; ii : $933-936$.

10. Sorlie PD. Feinleib M. The serum cholesterol-cancer relationship: An analysis of time trends in the Framingham Study. JNCl, 1982; 69: 989-996.

11. Schatzkin A, Hoover RN, Taylor PR, et al. Serum cholesterol and cancer in the NHANES I Epidemiologic Followup Study. Lancet, 1987: ii : 298-301.

12. Isles CG, Hole DJ, Gillis CR, Hawthorne VM, Lever AF. Plasma cholesterol, coronary heart disease, and cancer in the Renfrew and Paisley survey. BMJ, 1989; 298: 920924.

13. Bottiger LE, Carlson LA. Risk factors for death for males and females: A study of the death pattern in the Stockholm Prospective Study. Acta Med Scand. 1982; 211: 437-442.

14. Kagan A, McGee DL. Yano K, Rhoads GG, Nomura A. Serum cholesterol and mortality in a Japanese-American population: the Honolulu Heart Program. Am J Epidemiol, 1981: 114: 11-20.

15. Kark JD, Smith AH, Hames CG. The relationship of serum cholesterol to the incidence of cancer in Evans County, Georgia. J Chron Dis, 1980; 33: 311-322.

16. Salmond CE. Beaglehole R, Prior IAM. Are low cholesterol values associated with excess mortality? BMJ, 1985 ; 290: 422-424.

17. Kritchevsky SB. Dietary lipids and the low blood cholesterol-cancer association. Am J Epidemiol, 1992; 135: $509-520$.

18. Cowan LD, O'Connell DL, Criqui $\mathrm{MH}$, et al, Cancer mortality and lipid and lipoprotein levels: The Lipid Research Clinics Program Mortality Follow-up Study. 
Am J Epidemiol, 1990; 131: 468-482.

19. Schatzkin A, Hoover RN, Taylor PR, et al. Site-specific analysis of total serum cholesterol and incident cancer in the National Health and Nutrition Examination Survey I Epidemiologic Follow-up Study. Cancer Res, 1988; 48 : $452-458$.

20. Wallace RB, Rost C, Burmeister LF, Pomrehn PR. Cancer incidence in humans: Relationship to plasma lipids and relative weight. JNCI, 1982; 68: 915-918.

21. Cambien F, Ducimetiere P, Richard J. Total serum cholesterol and cancer mortality in a middle-aged male population. Am J Epidemiol, 1980; 112 : 388-394.

22. Sherwin RW, Wentworth DN, Culter JA, et al. Serum cholesterol levels and cancer mortality in 361,662 men screened for the Multiple Risk Factor Intervention Trial. JAMA, 1987 ; 257 : 943-948.

23. Stemmermann GN, Chyou P-H, Kagan A, Nomura AMY, Yano K. Serum cholesterol and mortality among Japanese-American men: the Honolulu (Hawaii) Heart Program. Arch Intern Med, 1991 ; 151: 969-972.

24. Garcia-Palmieri MR, Sorlie PD, Costas R, Jr., Havlik RJ. An apparent inverse relationship between serum cholesterol and cancer mortality in Puerto Rico. Am J Epidemiol, $1981 ; 114: 29-40$.

25. Keys A, Aravanis C, Blackburn H, et al. Serum cholesterol and cancer mortality in the Seven Countries Study. Am J Epidemiol, 1985; $121: 870-883$.

26. Knekt P, Reunanen A, Aromaa A, et al. Serum cholesterol and risk of cancer in a cohort of 39,000 men and women. J Clin Epidemiol, 1988: $41: 519-530$.

27. International Collaborative Group. Circulating cholesterol level and risk of death from cancer in men aged 40 to 69 years. JAMA, $1982 ; 248: 2853-2859$.

28. Wald NJ, Thompson SG, Law MR, Densem JW, Bailey A. Serum cholesterol and subsequent risk of cancer : results from the BUPA study. Br J Cancer, 1989; 59 : 936-938.

29. Hiatt RA, Fireman BH. Serum cholesterol and the incidence of cancer in a large cohort. J Chron Dis, 1986; 39 : $861-870$.

30. Tornberg SA, Holm L-E, Carstensen JM, Eklund GA. Cancer incidence and cancer mortality in relation to serum cholesterol. J Natl Cancer Inst, 1989; 81 : 1917-1921.

31. Gerhardsson M, Rosenquist U, Ahlbom A, Carlson LA. Serum cholesterol and cancer, a retrospective case-control study. Int J Epidemiol, 1986; 15: 155-159.

32. Morris DL, Borhani NO, Fitzsimons E, et al. Serum cholesterol and cancer in the Hypertension Detection and Follow-up Program. Cancer, 1983; 52: 1754-1759.

33. Hiatt R, Frieman B, Friedman G. Cholesterol and cancer. Am J Epidemiol, 1983; 118: 438.

34. Rose $G$, Blackburn $H$, Keys $A$, et al. Colon cancer and blood-cholesterol. Lancet, 1974; i : 181-183.

35. Wingard DL, Criqui MH, Holdbook MJ, Barrett-Connor E. Plasma cholesterol and cancer morbidity and mortality in an adult community. J Chronic Dis, 1984; 37 : $40 \mathrm{l}-406$.

36. Kromhout D, Bosschieter EB, Drijver $M$, Coulander CL. Serum cholesterol and 25-year incidence of and mortality from myocardial infarction and cancer: the Zutphen Study. Arch Intern Med, 1988 ; 148: 1051-1055.

37. Baptiste MS, Nasca PC, Doyle JT, et al. Cholesterol and cancer in a population of male civil service workers. Int J Epidemiol, 1992; $21:$ 16-22

38. Persson B, Johansson BW. The Kockum Study: Twenty-two-year follow-up. Acta Med Scand, 1984;
216: 485-493.

39. Shaper AG, Phillips AN, Pocock SJ. Plasma cholesterol, coronary heart disease and cancer. BMJ, 1989; 298: 1381.

40. Dyer AR, Stamler J, Paul O, et al. Serum cholesterol and risk of death from cancer and other causes in three Chicago epidemiological studies. J Chron Dis, 1981; 34: 249260.

41. Farchi G, Menotti A, Conti S. Coronary risk factors and survival probability from coronary and other causes of death. Am J Epidemiol, 1987 ; $126: 400-408$.

42. Carmelli D, Halpern J, Swan GE, et al. 27-year mortality in the Western Collaborative Group Study: Construction of risk groups by recursive partitioning. J Clin Epidemiol, 1991; 44: 1341-1351.

43. Thomas CB, Duszynski KR, Shaffer JW. Cholesterol levels in young adulthood and subsequent cancer: $A$ preliminary note. Johns Hopkins Med J, 1982; 150: 89-94.

44. Salonen JT. Risk of cancer and death in relation to serum cholesterol: a longitudinal study in an Eastern Finnish population with high overall cholesterol level. Am J Epidemiol, 1982 ; 116: 622-630.

45. Law MR, Thompson SG. Low serum cholesterol and the risk of cancer: An analysis of the published prospective studies. Cancer Causes Control, 1991; 2: 253-261.

46. Iida M, Tanigaki M, Naitou Y, et al. Life-expectancy of examinees of 'Junkanki-Kenshin' in Osaka. Jpn J Public Health, $1990: 37:$ S140 (in Japanese).

47. Jacobs D, Blackburn H, Higgins $M$, et al. Report of the conference on low blood cholesterol: Mortality associations. Circulation 1992; 86: 1046-1060.

48. Allain CC, Poon LS, Chan CSG, Richmond W, Fu PC. Enzymatic determination of total serum cholesterol. Clin Chem, 1974: 20:470-475.

49. Breslow NE, Day NE. Statistical Methods in Cancer Research, Volume 1, The Analysis of Case-Control Studies. IARC Scientific Publications No. 33, Lyon, 1980.

50. Williams RR, Sorlie PD, Feinleib M, et al. Cancer incidence by levels of cholesterol. JAMA, 1981; 245: 247252.

51. Kreger BE, Anderson KM, Schatzkin A, Splansky GL. Serum cholesterol level, body mass index, and the risk of colon cancer: the Framingham Study. Cancer, 1992; $70: 1038-1043$.

52. Stemmermann GN, Nomura AMY, Heilbrun LK, Pollack ES, Kagan A. Serum cholesterol and colon cancer incidence in Hawaiian Japanese men. JNCI, 1981; 67: 1179-1182.

53. Budd D, Ginsberg H. Hypocholesterolemia and acute myelogenous leukemia: Association between disease activity and plasma low-density lipoprotein cholesterol concentrations. Cancer, 1986; 58 : 1361-1365.

54. Henriksson P, Eriksson M, Ericsson S, et al. Hypocholesterolaemia and increased elimination of low-density lipoproteins in metastatic cancer of the prostate. Lancet, 1989 ; ii : $1178-1180$.

55. Feinleib $M$. On a possible inverse relationship between serum cholesterol and cancer mortality. Am J Epidemiol, $1981 ; 114: 5-10$.

56. Hlatky MA, Hulley SB. Plasma cholesterol: Can it be too low? Arch Intern Med, 1981; 141: 1132.

57. Sidney S, Farquhar JW. Cholesterol, cancer, and public health policy. Am J Med, $1983 ; .75: 494-508$. 
58. Freedman DS, Srinivasan SR, Shear CL, et al. Cigarette smoking initiation and longitudinal changes in serum lipids and lipoproteins in early adulthood: The Bogalusa Heart Study. Am J Epidemiol, 1986; $124: 207-219$.

59. Dwyer JH, Rieger-Ndakorerwa GE, Semmer NK, Fuchs R, Lippert P. Low-level cigarette smoking and longitudinal change in serum cholesterol among adolescents: The Berlin-Bremen Study. JAMA, 1988; $259: 2857-2862$.

60. Stubbe I, Eskilsson J, Nilsson-Ehle P. High-density lipoprotein concentrations increase after stopping smoking. Br Med J, 1982; $284: 1511-1513$.

61. de Parscau L, Fielding CJ. Abnormal plasma cholesterol metabolism in cigarette smokers. Metabolism, 1986; 35: 1070-73.

62. Holtzman EJ, Yaari S, Goldbourt U. Serum cholesterol and the risk of colorectal cancer. N Engl J Med, 1987 ; 317: 114 .

63. Hoyer AP, Engholm G. Serum lipids and breast cancer risk: A cohort study of 5,207 Danish women. Cancer Causes Control, 1992 ; 3 : 403-408.

64. Shekelle RB, Tangney CC, Rossof AH, Stamler J. Serum cholesterol, beta-carotene, and risk of lung cancer. Epidemiol, 1992 ; 3 : 282-287.

65. Feinleib M. Review of the epidemiological evidence for a possible relationship between hypocholesterolemia and cancer. Cancer Res, 1983; 43(Suppl) : 2503s-2507s.

66. Lowell JA, Parnes HL. Blackburn GL. Dietary immunomodulation: Beneficial effects on oncogenesis and tumor growth. Crit Care Med, 1990;18: S145-148.

67. Whiteside TL, Herberman RG. Characteristics of natural killer cells and lymphokine-activated killer cells. Their role in the biology and treatment of human cancer. Immunol Allergy Clin North Am, 1990; 10:667-704.

68. Connor WE, Hodges RE, Bleiler RE. Effect of dietary cholesterol upon serum lipids in man. J Lab Clin Med, $1961 ; 57: 331-342$.

69. Erickson BA, Coots RH, Mattson FH, Kigman AM. The Effect of partial hydrogenation of dietary fats, of the ratio of polyunsaturated to saturated fatty acids, and of dietary cholesterol upon plasma lipids in man. $\mathbf{J}$ Clin Invest, $1964 ; 43: 2017-2025$.

70. Keys A, Anderson IT, Grande F. Serum cholesterol response to changes in the diet. I-IV, Metabolism, 1965; $14: 747-787$.

71. Hegsted DM, McGandy RB, Myers ML, Stare FJ. Quantitative effects of dietary fat on serum cholesterol in man. Am J Clin Nutr, 1965; 17: 281-295.

72. Hursting SD, Thornquist M, Henderson MM. Types of dietary fat and the incidence of cancer at five sites. Prev Med, 1990; 19: 242-253.

73. Willett $W$. The search for the causes of breast and colon cancer. Nature, 1989; 338: 389-394.

74. McMichael AJ, Jensen OM, Parkin DM, Zaridze DG. Dietary and endogenous cholesterol and human cancer. Epidemiol Rev, 1984: 6: 192-216. 